\title{
The Effect of Learning Styles on Students' Mathematical Communication Ability
}

\author{
Tahir \\ Universitas Sembilanbelas November Kolaka \\ tahir.anwar.ta89@gmail.com
}

Received: November 2020; Accepted: December 2020; Published: January 2021

\begin{abstract}
This research is motivated by the low mathematical communication skills of students, where there are many factors that influence this, one of which is the student's learning style. This study aims to determine the effect of learning styles on students' mathematical communication skills. This type of research is ex post-facto research and was conducted at SMA Negeri 1 Mawasangka using a sample of 52 students. From the results of the analysis carried out, it was found that there was a relationship between student learning styles and students' mathematical communication abilities. This was because $r_{h i t}>r_{t a b}(0.38>0.27)$, the relationship formed was a positive one-way relationship because of the positive rhit value. In addition, from the one-way ANOVA, it was found that $F_{\text {count }}>F_{\text {table, }}$, it was concluded that there were differences in students' mathematical communication skills when viewed from their learning styles and this difference was significant. So it can be concluded that the learning style has an effect on students' mathematical communication skills, and this influence is a positive influence.
\end{abstract}

Keywords: learning styles, mathematical communication skills, influence.

How to cite: Tahir. (2021). The Effect of Learning Styles on Students' Mathematical Communication Ability. Journal of Medives: Journal of Mathematics Education IKIP Veteran Semarang, 5(1), 13-21. 


\section{PENDAHULUAN}

Matematika adalah salah satu mata pelajaran yang wajib dipelajari di setiap jenjang pendidikan, dari jenjang pendidikan dasar sampai pendidikan menengah atas. Dalam mempelajari matematika dibutuhkan kemampuan berpikir tingkat tinggi proses berpikir siswa dalam level kognitif yang lebih tinggi, dikembangkan dalam taksonomi pembelajaran (Megawati et al., 2019). Peran penting keterampilan berpikir tingkat tinggi berperan penting keterampilan dalam pembelajaran matematika terutama pada proses pembelajaran. Dengan kemapuan berpikir tingkat tinggi siswa akan terbiasa berpikir kritis dan kreatif baik dalam pengambilan keputusan dan pemecahan masalah yang berkaitan dengan menganalisis, mengevaluasi dan mencipta (Hidayati, 2017).

Salah satu dari kemampuan tingkat tinggi tersebut adalah kemamupan komunikasi matematis. Komunikasi matematika dapat diartikan sebagai suatu kemampuan siswa dalam menyampaikan sesuatu yang diketahuinya baik secara lisan maupun tulisan, baik dengan media maupun tanpa media (Hartati et al., 2017). National Council of Teachers of Mathematics (NCTM, 2000) menyatakan bahwa kemampuan komunikasi matematis merupakan salah satu kemampuan tingkat tinggi sangat penting dalam matematika dan pembelajaran matematika. Bahkan para matematikawan mengungkapkan kemampuan komunikasi matematis adalah salah satu kompetensi yang perlu diupayakan peningkatannya sebagaimana kompetensi lainnya seperti kompetensi bernalar dan kompetensi pemecahan masalah agar pembelajaran matematika memperoleh hasil yang maksimal (Daimaturrohmatin \& Rufiana, 2019).

Namun kenyataan di lapangan kemampuan komunikasi matematis siswa masih jauh dari yang diharapkan (Nasruddin \& Jahring, 2019). Hal ini di temukan oleh peneliti di SMA Negeri 1 Mawasangka, dari hasil pengamatan awal yang dilakukan dengan melakukan wawancara dan menganalisis hasil ulangan harian siswa diperoleh informasi bahwa kemampuan komunikasi matematis siswa masih sangat kurang terutama pada indikator Menjelaskan ide, situasi, dan relasi matematika secara lisan atau tulisan dengan benda nyata, gambar, dan aljabar, serta pada indikator menyatakan peristiwa sehari-hari dalam bahasa atau simbol matematika.

Ada banyak faktor yang mempengaruhi penguasaan kemampuan komunikasi matematis siswa. Salah satunya adalah gaya belajar siswa, sebab gaya belajar terkait dengan cara masingmasing siswa dalam menerima, menganalisis, mengevaluasi dan mengkreasikan informasi yang diperolehnya (Purbaningrum, 2017). De Porter berpendapat dengan mengetahui gaya belajar siswa telah membantu para guru dimana pun untuk dapat menyampaikan informasi dengan baik kepada siswa (Masitoh \& Prabawanto, 2016). Lucy membagi gaya belajar menjadi tiga yaitu gaya belajar visual, audio, dan kinestik atau yang disingkat VAK (Wijayanti et al., 2019). Selanjutnya Fleming (2006) yang membagi gaya belajar menjadi 4 komponen, yaitu visual, auditory, read/write, dan kinestetic yang disingkat dengan VARK (Ahmad, 2018). 
Shah (2013) VARK mendefinisikan preferensi gaya belajar dalam hal gaya sensorik dimana seorang siswa lebih suka mengambil informasi baru. Siswa dengan kecenderungan gaya visual umumnya senang menggunakan media visual seperti diagram, grafik, diagram alir, dan model yang mewakili informasi visual. Pelajar auditory lebih suka informasi yang didengar, sehingga cara terbaik untuk belajar adalah diskusi, ceramah, berbicara dengan diri sendiri dan orang lain. Pelajar yang cenderung read/write lebih suka kata-kata dan buku teks sebagai cara untuk mendapatkan informasi, sehingga lebih senang buku pelajaran, kuliah catatan, selebaran, daftar dan glosarium. Selanjutnya, siswa dengan kecenderungan kinestetik menggunakan kombinasi fungsi sensorik, mereka harus merasakan atau menghayati pengalaman belajarnya, lebih suka simulasi praktek dan pengalaman nyata, pelajaran yang menekankan pada melakukan suatu kegiatan, perjalanan, pameran, sampel, studi kasus dan role play (Jahring \& Chairuddin, 2019).

Selain hal di atas, hasil penelitian dari (Danaryanti \& Noviani, 2015) yang berkesimpulan bahwa gaya belajar siswa kelas VII berpengaruh terhadap kemampuan komunikasi matematis dalam menyelesaikan soal uraian matematika, dan penelitian yang dilakukan oleh (Nurhidayah, 2015) berkesimpulan bahwa gaya belajar berpengaruh terhadap prestasi matematik siswa.

Dari penjelasan di atas, maka peneliti bermaksud melakukan penelitian yang bertujuan untuk mengetahui pengaruh dari gaya belajar terhadap kemampuan komunikasi matematis siswa.

\section{METODE PENELITIAN}

Penelitian yang dilakukan adalah pengkajian mengenai pengaruh gaya belajar terhadap kemampuan komunikasi matematis siswa. Penelitian ini menggunakan metode expost-facto. Penelitian ini dilaksanakan di kelas XI IPA SMA Negeri 1 Mawasangka. Karena jumlah populasi hanya 52 orang siswa maka metode sampel yang digunakan adalah sampel jenuh dimana semua populasi menjadi sampel.

Data penelitian diperoleh melalui dua cara yaitu menggunakan metode kuesioner (angket) untuk memperoleh data gaya belajar siswa dan tes untuk menilai kemampuan komunikasi matematis siswa. Angket yang digunakan adalah kuisioner VARK yang berisi 16 pertanyaan baku terkait modalitas belajar yang merupakan kuisioner baku yang diambil dari The VARK Questionnaire Version 7.1 yang disadur dari www.varklearn.com. Sedangkan untuk memperoleh data kemampuan komunikasi matematis siswa peneliti membuat soal tes kemampuan komunikasi matematis dimana tes tersebut dibuat sesuai dengan materi yang telah dipelajari oleh siswa dan disusun berdasarkan indikator kemampuan komunikasi matematis dan terlebih dahulu di uji coba untuk di ukur validitas, reabilitas, tingkat kesukaran dan daya pembedanya. Data gaya belajar siswa dikonversi dari data ordinal menjadi data interval. Sedangkan untuk mengkategorikan kemampuan komunikasi matematis (KKM) digunakan interpretasi pada Tabel 1. 
Tabel 1. Kategori KKM

\begin{tabular}{lcl}
\hline No. & Rentang Nilai KKM & Kategori \\
\hline 1. & $\mathrm{X} \geq 71,17$ & Tinggi \\
2. & $33,06 \leq \mathrm{X}<71,17$ & Sedang \\
3. & $\mathrm{X}<33,06$ & Rendah \\
\hline
\end{tabular}

Selanjutnya untuk melihat hubungan antara gaya belajar dengan kemampuan komunikasi matematis siswa, data yang diperoleh dianalisis menggunakan analisis korelasi product momen pearson dengan rumus

$$
r_{x y}=\frac{n \sum_{i=1}^{n} X_{i} Y_{i}-\left(\sum_{i=1}^{n} X_{i}\right)\left(\sum_{i=1}^{n} Y_{i}\right.}{\sqrt{\left(n \sum_{i=1}^{n} X_{i}^{2}-\left(\sum_{i=1}^{n} X_{i}\right)^{2}\right)\left(n \sum_{i=1}^{n} Y_{i}^{2}-\left(\sum_{i=1}^{n} Y_{i}\right)^{2}\right)}}
$$

(Sugiyono, 2016).

Hasil analisis korelasinya diinterpretasi menurut Tabel 2.

Tabel 2. Interpretasi Nilai $r$

\begin{tabular}{cl}
\hline Interval Koefisien & \multicolumn{1}{c}{$\begin{array}{c}\text { Tingkat } \\
\text { Hubungan }\end{array}$} \\
\hline $0,80-1,000$ & Sangat Kuat \\
$0,60-0,799$ & Kuat \\
$0,40-0,599$ & Cukup Kuat \\
$0,20-0,399$ & Rendah \\
$0,00-0,199$ & Sangat Rendah \\
\hline & (Sugiyono, 2016)
\end{tabular}

Hubungan antara perbedaan kemampuan komunikasi matematis bila dilihat dari gaya belajarnya dianalisis menggunakan Anova satu jalur dengan rumus dapat dilihat pada Tabel 3.

\section{HASIL DAN PEMBAHASAN}

Setelah pemberian angket gaya belajar VARK dan tes kemampuan komunikasi matematis (KKM) diperoleh hasil sebagaimana pada Tabel 4.

Tabel 4. Rekapitulasi Data Penelitian

\begin{tabular}{ccccc}
\hline No & Aspek & n & $\begin{array}{c}\text { Rata- } \\
\text { Rata }\end{array}$ & $\begin{array}{c}\text { Standar } \\
\text { Deviasi }\end{array}$ \\
\hline 1. & Gaya & 52 & 34,50 & 9,78 \\
2. & KKM & 52 & 52,12 & 19,05 \\
\hline
\end{tabular}

Dari Tabel 4, diperoleh bahwa dari 52 siswa yang diberi angket gaya belajar VARK didapat rata-rata 34,50 dan standar deviasi 9,78. Sedangkan hasil tes KKM dari 52 siswa diperoleh rata-rata 52,12 dimana ini berada pada kategori sedang dengan standar deviasi 19,05.

Tabel 3. Anova Satu Jalur

\begin{tabular}{|c|c|c|c|c|c|}
\hline $\begin{array}{l}\text { Sumber } \\
\text { Varians }\end{array}$ & Jumlah Kuadrat (JK) & $\begin{array}{c}\text { Derajat } \\
\text { Bebas } \\
\text { (db) }\end{array}$ & $\begin{array}{c}\text { Kuadrat Rerata } \\
(\text { KR) }\end{array}$ & $F_{\text {Hitung }}$ & $F_{\text {Tabel }}$ \\
\hline $\begin{array}{l}\text { Antar } \\
\text { Grup } \\
\text { (A) }\end{array}$ & $J K(A)=\sum_{i=1}^{a} \frac{\left(\sum_{i=1}^{n_{i}} Y\right)^{2}}{n_{i}}-$ & $n_{a}-1$ & $R J K(A)=\frac{J K(A)}{d b(A)}$ & $\frac{R J K(A)}{R J K(D)}$ & $\begin{array}{c}\text { Dilihat } \\
\text { pada } \\
\text { tabel F } \\
\text { dengan }\end{array}$ \\
\hline $\begin{array}{l}\text { Dalam } \\
\text { Grup } \\
\text { (D) }\end{array}$ & $J K(D)=\sum_{i=1}^{a} \mid \sum_{i=1}^{n_{i}} Y_{i}^{2}-\frac{\left(\sum_{i=1}^{n_{i}}\right.}{r}$ & $n_{t}-n_{a}$ & $R J K(D)=\frac{J K(D)}{d b(D)}$ & & $\alpha=0,05$ \\
\hline Total & $J K(T)=\sum_{t=1}^{n_{t}} Y_{t}^{2}-\frac{\left(\sum_{t=1} Y_{t}\right.}{n_{t}}$ & $n_{t}-1$ & & & \\
\hline
\end{tabular}


Selanjutnya data kemampuan komunikasi matematis dipisah berdasarkan gaya belajar siswa, dan diperoleh hasil yang terangkum dalam Tabel 5.

Tabel 5. Klasifikasi KKM Berdasarkan Gaya Belajar Siswa

\begin{tabular}{llccl}
\hline No & $\begin{array}{c}\text { Gaya } \\
\text { Belajar }\end{array}$ & n & $\begin{array}{c}\text { Rata- } \\
\text { Rata } \\
\text { KKM }\end{array}$ & Kriteria \\
\hline 1. & Unimodal & 20 & 46,25 & Sedang \\
2. & Bimodal & 9 & 42,78 & Sedang \\
3. & Trimodal & 9 & 57,78 & Sedang \\
4. & Quadmodal & 14 & 62,86 & Sedang \\
\hline
\end{tabular}

Berdasarkan Tabel 5, terlihat bahwa terdapat 20 siswa bergaya belajar Unimodal dengan rata-rata KKM 46,25, 9 orang siswa bergaya belajar Bimodal dan Trimodal dengan rata-rata KKM berturut-turut 42,78 dan 57,78, serta terdapat 14 orang siswa bergaya belajar Quadmodal dengan rata-rata KKM 62,86 .

Untuk mengetahui hubungan dari gaya belajar dan kemampuan komunikasi matematis, keseluruhan data dianalisis korelasi dengan rumusan hipotesis penelitian sebagai berikut.

$\mathrm{H}_{0}$ : tidak ada hubungan yang signifikan antara gaya belajar dengan kemampuan komunikasi matematis siswa.

$\mathrm{H}_{1}$ : ada hubungan yang signifikan antara gaya belajar dengan kemampuan komunikasi matematis siswa.
Dengan taraf signifikansi 0,05 diperoleh $r_{\text {hit }}=0,38$ dan $r_{\text {tab }}=0,27$. Diperoleh $r_{\text {hit }}>r_{\text {tab }}$ sehingga $\mathrm{H}_{0}$ ditolak dan $\mathrm{H}_{1}$ diterima maka disimpulkan bahwa terdapat hubungan yang signifikan antara gaya belajar dengan kemampuan komunikasi matematis siswa. Selanjutnya, koifisien korelasi sebesar 0,38 menunjukkan bahwa pola hubungan yang terbentuk adalah hubungan searah. Hal ini menunjukkan bahwa jika gaya belajar siswa rendah maka akan diikuti dengan rendahnya kemampuan komunikasi matematisnya, begitu pula sebaliknya. Namun hubungan yang terbentuk berada pada kategori rendah.

Untuk melihat perbedaan kemampuan komunikasi matematis siswa bila dilihat dari gaya belajarnya, data statistik diolah dengan anova satu jalur dengan hipotesis sebagai berikut:

$\mathrm{H}_{0}$ : tidak terdapat perbedaan kemampuan komunikasi matematis yang signifikan antara siswa dengan gaya belajar Unimodal, Bimodal, Trimodal dan Quad Modal.

$\mathrm{H}_{1}$ : terdapat perbedaan kemampuan komunikasi matematis yang signifikan antara siswa dengan gaya belajar Unimodal, Bimodal, Trimodal dan Quad Modal.

Hasil analisis data tersebut dapat dilihat pada Tabel 6. Dari Tabel 6, diperoleh bahwa $F_{\text {Hitung }}>F_{\text {Tabel }}$ sehingga $H_{0}$ ditolak

Tabel 6. Ringkasan Anova Satu Jalur

\begin{tabular}{lccccc}
\hline \multicolumn{1}{c}{$\begin{array}{c}\text { Sumber } \\
\text { Varians }\end{array}$} & $\begin{array}{c}\text { Jumlah } \\
\text { Kuadrat (JK) }\end{array}$ & $\begin{array}{c}\text { Derajat } \\
\text { Bebas }(\mathbf{d b})\end{array}$ & $\begin{array}{c}\text { Kuadrat } \\
\text { Rerata (KR) }\end{array}$ & $\boldsymbol{F}_{\text {Hitung }}$ & $F_{\text {Tabel }}$ \\
\hline Antar group (A) & 3376,73 & 3 & 1125,58 & 3,57 & 2,8 \\
$\begin{array}{l}\text { Dalam group } \\
\text { (D) }\end{array}$ & 15140,58 & 48 & 315,43 & & \\
Total & 18517,31 & 51 & - & & \\
\hline
\end{tabular}


dan $\mathrm{H}_{1}$ diterima dalam artian terdapat perbedaan yang signifikan Kemampuan komunikasi matematis antara siswa dengan gaya belajar Unimodal, Bimodal, Trimodal dan Quad Modal.

Karena $H_{0}$ ditolak maka dilakukan uji lanjut, untuk menentukan uji lanjut yang akan digunakan maka terlebih dahulu dilakukan uji homogenitas dengan menggunakan uji bartlet dan hasilnya dapat dilihat pada Tabel 7.

Tabel 7. Hasil Uji Homogenitas

\begin{tabular}{cccccc}
\hline Uji & $\mathbf{k}$ & $\chi_{h i t}^{2}$ & $\mathbf{d b}$ & $\chi_{\text {tab }}^{2}$ & $\begin{array}{c}\text { Kesim- } \\
\text { pulan }\end{array}$ \\
\hline Bartlet & 4 & 0,50 & 3 & 7,82 & homogen \\
\hline
\end{tabular}

Dari Tabel 7 diperoleh bahwa kelompok data memiliki varians yang sama maka post hoc test dilakukan dengan menggunakan uji t Dunnet. Hasil uji $\mathrm{t}$ Dunnet dengan hipotesis $H_{0}: \mu_{i} \leq \mu_{j}$ dan $H_{a}: \mu_{i}>\mu_{j}$ dengan $\mathrm{i}, \mathrm{j}=1$, 2, 3, 4 ditampilkan pada Tabel 8.

Tabel 8. Hasil Uji t Dunnet

\begin{tabular}{cccc}
\hline No. & Variabel & $t_{\text {hit }}$ & $t_{\text {tab }}$ \\
\hline 1 & $Y_{1}-Y_{2}$ & 0,49 & \\
2 & $Y_{1}-Y_{3}$ & $-1,62$ & \\
3 & $Y_{1}-Y_{4}$ & $-2,68$ & \\
4 & $Y_{2}-Y_{3}$ & $-1,79$ & 1,68 \\
5 & $Y_{2}-Y_{4}$ & $-2,65$ & \\
6 & $Y_{3}-Y_{4}$ & $-0,67$ & \\
\hline
\end{tabular}

Dari Tabel 8 dapat ditentukan hasil sebagai berikut.

1. Untuk $Y_{1}$ dan $Y_{2}$ diperoleh $t_{h i t} \leq t_{\text {tab }}$ maka $H_{0}$ diterima dalam artian kemampuan komunikasi matematis siswa yang memiliki gaya belajar bimodal lebih baik dari kemampuan komunikasi matematis siswa yang memiliki gaya belajar unimodal.

2. Untuk $Y_{1}$ dan $Y_{3}$ diperoleh $t_{h i t} \geq$ $-t_{\text {tab }}$ maka $H_{0}$ diterima dalam artian kemampuan komunikasi matematis siswa yang memiliki gaya belajar trimodal lebih baik dari kemampuan komunikasi matematis siswa yang memiliki gaya belajar unimodal.

3. Untuk $Y_{1}$ dan $Y_{4}$ diperoleh $t_{h i t}<-t_{\text {tab }}$ maka $H_{0}$ ditolak dalam artian kemampuan komunikasi matematis siswa yang memiliki gaya belajar unimodal lebih baik dari kemampuan komunikasi matematis siswa yang memiliki gaya belajar quadmodal.

4. Untuk $Y_{2}$ dan $Y_{3}$ diperoleh $t_{h i t}<-t_{\text {tab }}$ maka $H_{0}$ ditolak dalam artian kemampuan komunikasi matematis siswa yang memiliki gaya belajar bimodal lebih baik dari kemampuan komunikasi matematis siswa yang memiliki gaya belajar trimodal.

5. Untuk $Y_{2}$ dan $Y_{4}$ diperoleh $t_{h i t}<-t_{\text {tab }}$ maka $H_{0}$ ditolak dalam artian kemampuan komunikasi matematis siswa yang memiliki gaya belajar bimodal lebih baik dari kemampuan komunikasi matematis siswa yang memiliki gaya belajar quadmodal.

6. Untuk $Y_{3}$ dan $Y_{4}$ diperoleh $t_{h i t} \geq$ $-t_{\text {tab }}$ maka $H_{0}$ diterima dalam artian kemampuan komunikasi matematis siswa yang memiliki gaya belajar quadmodal lebih baik 
dari kemampuan komunikasi matematis siswa yang memiliki gaya belajar trimodal.

Selanjutnya untuk mengetahui besar pengaruh gaya belajar siswa terhadap kemampuan komunikasi matematis siswa maka koifisien determinasi yaitu $R^{2}=\frac{J K(A)}{J K(T)}=0,1824$ hal ini memberi arti bahwa gaya belajar siswa dapat menjelaskan sebesar $18,24 \%$ variasi kemampuan komunikasi belajarnya.

Setelah melakukan semua rangkaian analisis data, ditemukan bahwa terdapat hubungan antara gaya belajar dengan kemampuan komunikasi matematis siswa. Pola hubungan yang terbentuk adalah hubungan searah, yaitu apabila gaya belajar yang tinggi akan menyebabkan tinggi pula kemampuan komunikasi matematis siswa. Sebaliknya, jika gaya belajar siswa rendah maka akan berakibat pada rendahnya rendahnya kemampuan komunikasi matematis siswa. Meskipun hubungan yang terjadi antara kedua variabel masuk pada kategori rendah. Sedangkan bila kemampuan komunikasi matematis siswa dibagi berdasarkan gaya belajarnya mengikuti analisis gaya belajar VARK, maka diperoleh terdapat empat model gaya belajar siswa yaitu gaya belajar Unimodal, Bimodal, Trimodal, dan Quadmodal. Selanjutnya dari hasil uji perbedaaan kemampuan komunikasi matematis siswa yang didasarkan gaya belajarnya diperoleh hasil terdapat perbedaan yang signifikan. Hal ini memberi arti bahwa dalam pembelajaran matematika guru perlu memperhatikan gaya belajar siswanya, terutama apa bila guru ingin memberikan suatu perlakuan. Bila kita melihat pada Tabel 5, nampak bahwa semakin banyak variasi gaya belajar siswa semakin tinggi pula kemampuan komunikasi matematisnya meskipun secara kategori semua masih masuk dalam kategori sedang.

Hasil yang diperoleh pada penelitian ini sejalan dengan pendapat Porter yang dituliskan di awal bahwa mengetahui gaya belajar siswa akan membantu para guru dimana pun untuk dapat menyampaikan informasi dengan baik kepada siswa. Hasil ini juga sejalan dengan hasil-hasil penelitian yang relevan. Selain itu dengan adanya data tentang preferensi modalitas belajar siswa ini, guru diharap untuk mengembangkan strategi mengajar dalam meningkatkan kemampuan komunikasi matematis siswa. Sebab kemapuan komunikasi matematis siswa merupakan salah satu faktor pengting dalam belajar matematika seperti pernyataan NCTM bahwa kemampuan komunikasi matematis merupakan salah satu kemampuan tingkat tinggi sangat penting dalam matematika dan pembelajaran matematika.

\section{PENUTUP}

Dari hasil analisis yang dilakukan diperoleh bahwa terdapat hubungan anatara gaya belajar siswa dengan kemampuan komunikasi matematis siswa hal ini karena $r_{\text {hit }}>r_{\text {tab }}$, hubungan yang terbentuk adalah hubungan yang searah positif karena nilai $r_{\text {hit }}$ yang positif. selain itu, dari anova satu jalur diperoleh bahwa terdapat perbedaan 
kemampuan komunikasi matematis siswa bila dilihat dari gaya belajarnya dan perbedaan ini perbedaan yang signifikan. Sehingga dapat disimpulkan bahwa gaya belar berpengaruh terhadap kemampuan komunikasi matematis siwa, dan pengaruh tersebut adalah pengaruh positif.

\section{DAFTAR PUSTAKA}

Ahmad, D. N. (2018). Pengaruh Gaya Belajar Peserta Didik Terhadap Pemahaman Konsep Sistem Peredaran Darah Pada Manusia di Sekolah Menengah Atas Negeri 11 Depok. PEMBELAJAR: Jurnal Ilmu Pendidikan, Keguruan, Dan Pembelajaran. https://doi.org/10.26858/pembelaj ar.v2i1.5010

Daimaturrohmatin, D., \& Rufiana, I. S. (2019). Analisis Kemampuan Komunikasi Matematis Siswa Ditinjau Dari Gaya Belajar Kolb. EDUPEDIA. https://doi.org/10.24269/ed.v3i1.2 32

Danaryanti, A., \& Noviani, H. (2015). Pengaruh Gaya Belajar Matematika Siswa Kelas VII terhadap Kemampuan Komunikasi Matematis di SMP. EDU-MAT: Jurnal Pendidikan Matematika. https://doi.org/10.20527/edumat.v $3 \mathrm{i} 2.648$

Hartati, S., Abdullah, I., \& Haji, S. (2017). Pengaruh Kemampuan Pemahaman Konsep, Kemampuan Komunikasi dan Koneksi Terhadap Kemampuan Pemecahan Masalah. MUST: Journal of Mathematics Education, Science and Technology. https://doi.org/10.30651/must.v2i 1.403
Hidayati, A. U. (2017). Elatih Keterampilan Berpikir Tingkat Tinggi Dalam Pembelajaran Matematika Pada Siswa Sekolah Dasar Arini. Pendidikan Dan Pebelajaran Dasar.

Jahring, J., \& Chairuddin, C. (2019). Preferensi Modalitas Belajar Mahasiswa Angkatan 2016 Program Studi Pendidikan Matematika Universitas Sembilanbelas November Kolaka. Square: Journal of Mathematics and Mathematics Education. https://doi.org/10.21580/square.v1 i1.4039

Kadir. (2015). "Statistika Terapan: Konsep, Contoh dan Analisis Data dengan. Program SPSS/Lisrel dalam Penelitian.” Rajawali.

Masitoh, I., \& Prabawanto, S. (2016). Peningkatan Pemahaman Konsep Matematika dan Kemampuan Berfikir Kritis Matematis Siswa Kelas V Sekolah Dasar Melalui Pembelajaran Eksloratif. EduHumaniora | Jurnal Pendidikan Dasar Kampus Cibiru. https://doi.org/10.17509/eh.v7i2.2 709

Megawati, M., Wardani, A. K., \& Hartatiana, H. (2019). Kemampuan Berpikir Tingkat Tinggi Siswa Smp Dalam Menyelesaikan Soal Matematika Model Pisa. Jurnal Pendidikan Matematika.

https://doi.org/10.22342/jpm.14.1. 6815.15-24

Nasruddin, N., \& Jahring, J. (2019). Efektivitas Penerapan Model Pembelajaran Reciprocal Teaching dalam Meningkatkan Kemampuan Komunikasi Matematis Siswa. SAINTIFIK. https://doi.org/10.31605/saintifik. 
v5i1.195

Nurhasanah. (2014). Pengaruh Gaya Belajar Terhadap Prestasi Belajar Matematika Siswa Kelas VII SMP Yapis Manokwari. Universitas Рариа, 2(2), 173-182.

Nurhidayah, D. A. (2015). Pengaruh Motivasi Berprestasi dan Gaya Belajar Terhadap Prestasi Belajar Siswa Pada Mata Pelajaran Matematika SMP. Jurnal Dimensi Pendidikan dan Pembelajaran. https://doi.org/http://dx.doi.org/10 $.24269 /$ dpp.v3i2.83

Purbaningrum, K. A. (2017). Kemampuan Berpikir Tingkat Tinggi Siswa SMP Dalam Pemecahan Masalah Matematika Ditinjau Dari Gaya Belajar. Jurnal Penelitian Dan Pembelajaran Matematika. https://doi.org/10.30870/jppm.v10 i2. 2029

Sugiyono. (2016). Satistika Untuk Penelitian. Alfabeta.

Wijayanti, I. D., Hariastuti, R. M., \& Yusuf, F. I. (2019). Kemampuan Komunikasi Matematis Siswa Ditinjau dari Gaya Belajar. Indiktika: Jurnal Inovasi Pendidikan Matematika. https://doi.org/10.31851/indiktika. v2i1.3429 